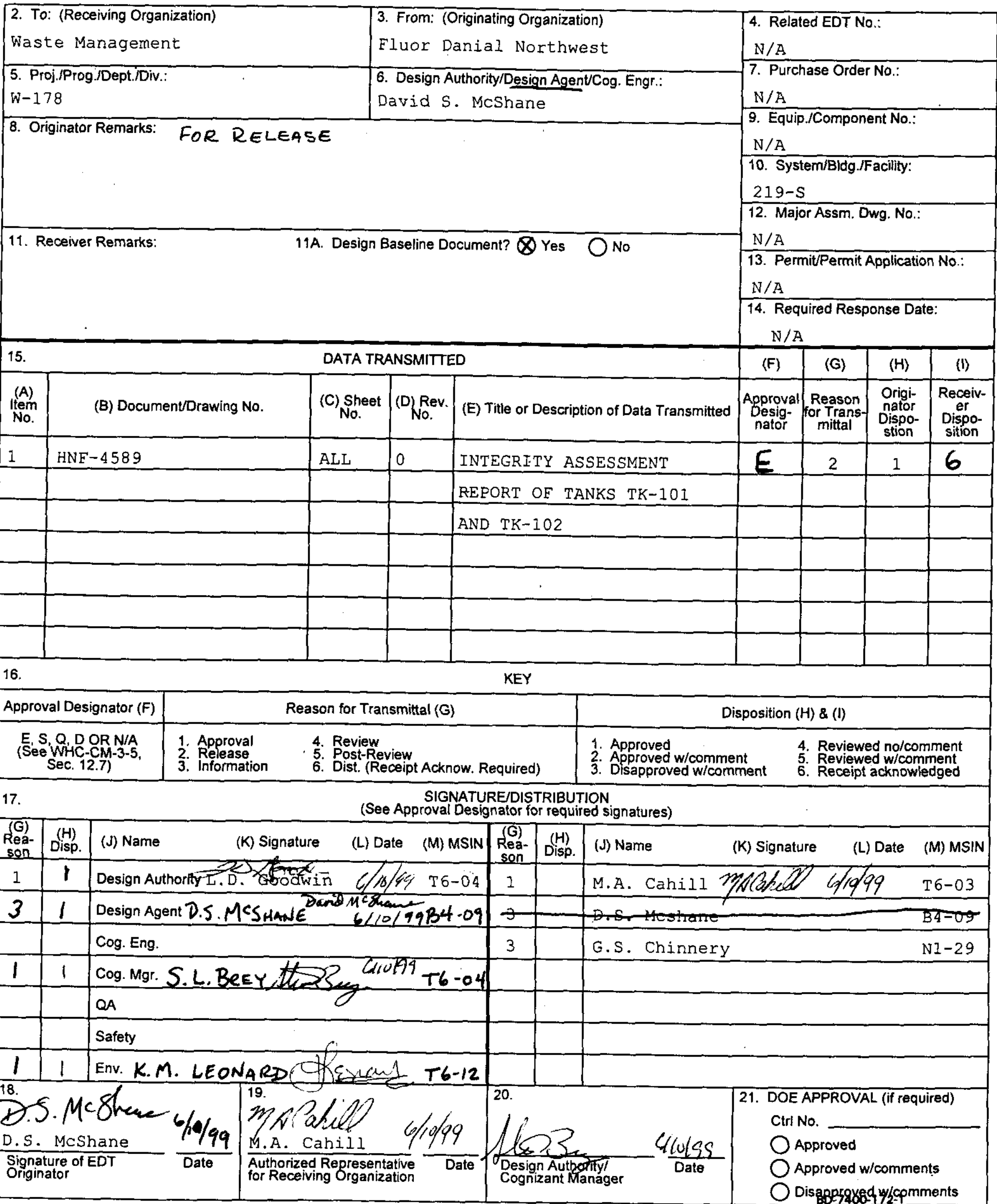




\section{Integrity Assessment Report of Tanks TK-101 and TK-102}

David S. McShane

Fluor Daniel Northwest

Richland, WA 99352

U.S. Department of Energy Contract DE-AC06-96RL13200

EDT/ECN: 620989

Org Code: 08000

B\&R Code:

EW 3130000
UC:

Charge Code: 101773

Total Pages: 13

Key Words: Integrity Assessment, $W-178, w-087,219-5,222-S$, Tanks TK-101 and TK-102

Abstract: Integrity assessment of TK-101 and TK-102 for project W-178.

TRADEMARK DISCLAIMER. Reference herein to any specific commercial product, process, or service by trade name, trademark, manufacturer, or otherwise, does not necessarily constitute or imply its endorsement, recommendation, or favoring by the United States Government or any agency thereof or its contractors or subcontractors.

Printed in the United States of America. To obtain copies of this document, contact: Document Control Services, P.O. Box 950, Mailstop H6-08, Richland WA 99352, Phone (509) 372-2420; Fax (509) 376-4989.
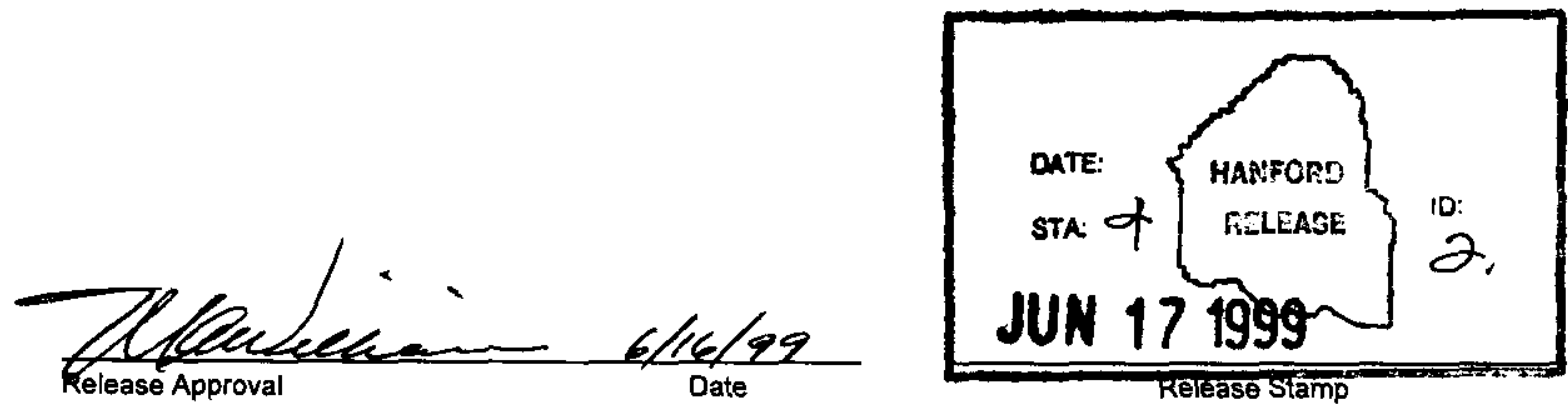

Approved For Public Release 


\title{
INTEGRITY ASSESSMENT REPORT OF TANKS TK-101 AND TK-102
}

\section{PROJECT W-178 \\ 219-S SECONDARY CONTAINMENT UPGRADE}

\author{
Prepared for \\ Waste Management Hanford
}

Prepared by

David S. McShane P.E.

Fluor Daniel Northwest 


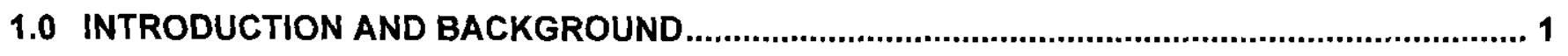

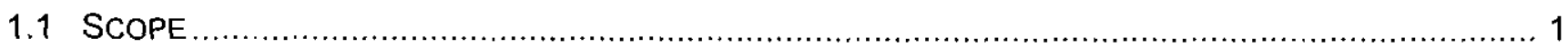

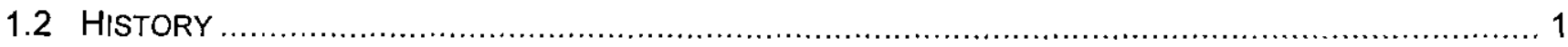

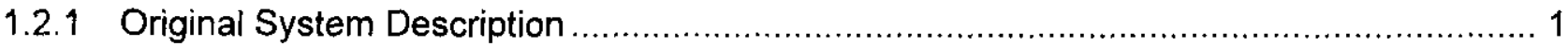

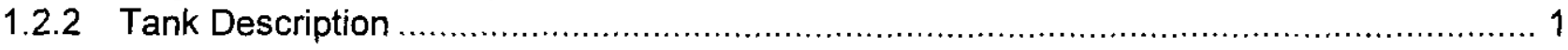

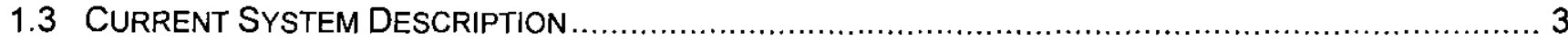

2.0 INTEGRITY OF TANKS 101 AND 102 AND EXISTING COMPONENTS OF THE 219-S

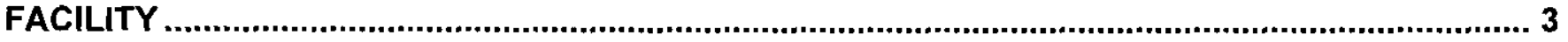

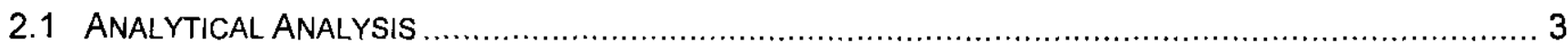

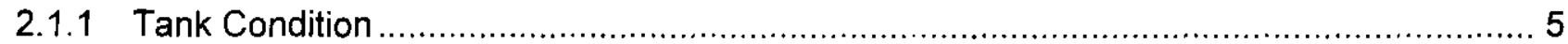

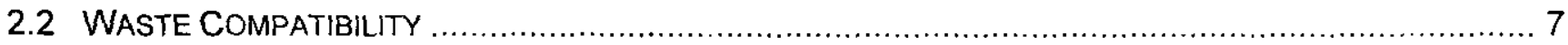

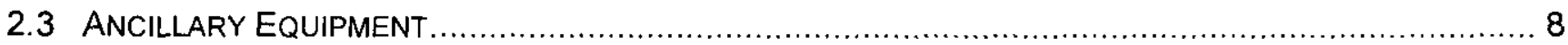

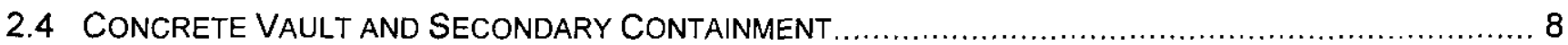

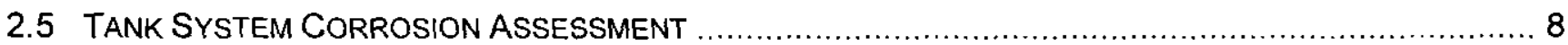

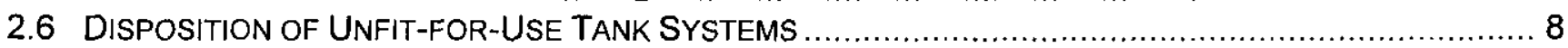

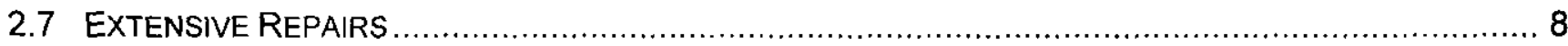

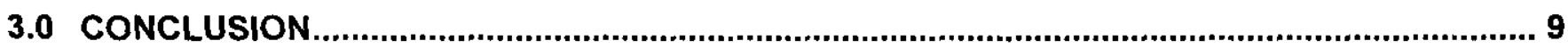

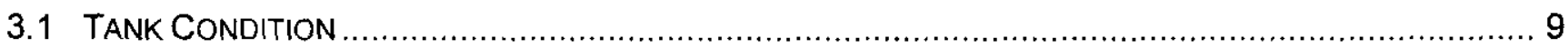

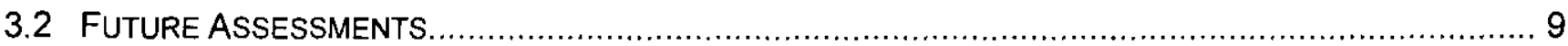

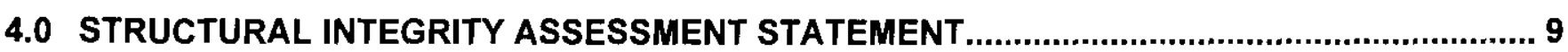

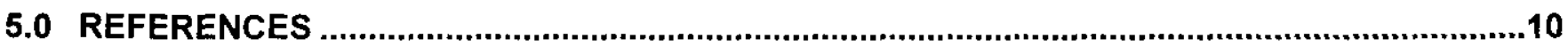

\section{FIGURES}

Figure $1 \quad$ Sketch of Tanks 101 and 102

Figure 2 Waste Transfer System

Figure 3 Seismic Restraints for Tanks 101 and 102

\section{TABLES}

Table $1 \quad$ Waste Characteristics 


\subsection{INTRODUCTION AND BACKGROUND}

\subsection{Scope}

This Integrity Assessment Report (IAR) is prepared by Fluor Daniel Northwest (FDNW) for Waste Management Federal Services of Hanford, Inc., (WMH), the operations contractor; Fluor Daniel Hanford (FDH), the Hanford Site Manager; and the U. S. Department of Energy (DOE), the system owner. This IAR addresses the evaluation of Tanks 101 and 102 and other existing components located in the 219-S Waste Handling Facility. This report will be included in the Part B Permit for the 222-S Laboratory and is a portion of the integrity assessment of the overall 222-S Laboratory radioactive liquid waste disposal system. This IAR is prepared in accordance with WAC 173-303, Dangerous Waste Regulations; Section 640(2), "Assessment of Existing Tank Systems Integrity."(Reference 1).

\subsection{History}

\subsubsection{Original System Description}

The 219-S Facility was built in the early 1950's and is part of the 222-S Laboratory radioactive liquid waste disposal system. The 219-S Facility originally consisted of three tanks (Tanks 101, 102, and 103) enclosed in an underground, epoxy-coated, concrete vault, interconnecting piping, an operating gallery, and sampling room. This vault was separated into two sections (Cell $A$ and Cell B) with each section sloped to a sump equipped with a steam jet to remove waste and level instrument with an alarm. Tanks 101 and 103 collected waste from the laboratory through underground lines. When enough waste was collected, waste would be transferred to the third tank (Tank 102) via a steam jet system. In Tank 102, the $\mathrm{pH}$ and nitrite levels of the waste would be adjusted prior to transfer to the tank farms. Transfer to the tank farms was originally made through an underground line routed through REDOX. However, from 1989 to 1998, the waste transfers were made by a tanker trailer. The laboratory uses a large variety of chemicals. The most frequently used chemicals, which could corrode the stainless steel tanks, are hydrochloric acid, nitric acid, carbonate, hydroxide, fluoride, nitrite, sulfate, and phosphate.

\subsubsection{Tank Description}

Tanks 101 and 102 are 4300 gallon ( $9 \mathrm{ft}-0$ in. diameter by $9 \mathrm{ft}-8$ in. tall) stainless steel tanks fabricated in 1943 for U Plant (see Reference 2). The U Plant work was canceled before the tanks were installed. The tanks were secured for the 219 S Facility and placed into service in 1951. Both tanks were built to ASME standards (non code stamped) from Type 347 stainless steel with a shell thickness of 0.5 inches. The tanks were fabricated from plate connected with full penetration welds. The welding was radiographed. Each tank is equipped with a cooling jacket that covers the lower half of the tank. The tanks are designed to be operated at atmospheric pressure. The high-level alarm on Tank 101 set at 3600 gallons and Tank 102 set at 3800 gallons. A sketch of the tanks is shown in Figure 1. When installed in 1951, Tank 102 (functioning as a chemical treatment tank) was equipped with an agitator. Tank 101 (functioning as a collection tank) was not equipped with an agitator. 
Figure 1,

Sketch of Tanks 101 and 102

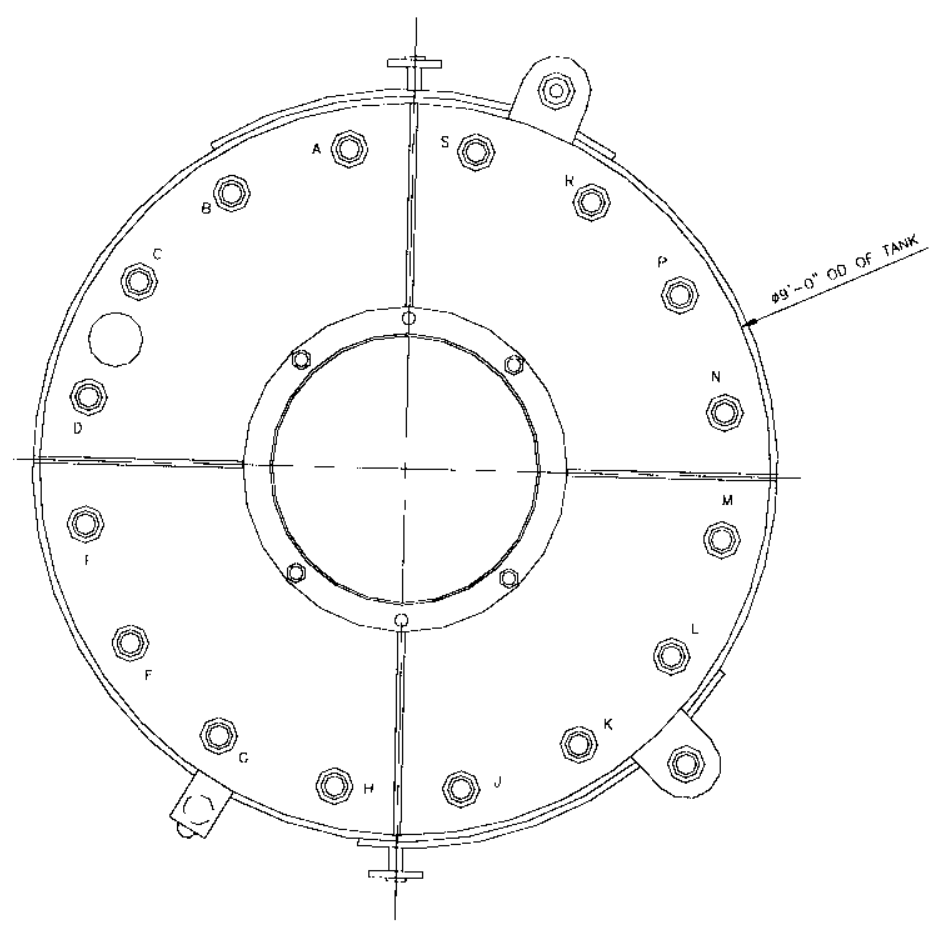

TANK NO. $101 \frac{\text { PLAN }}{\text { AND }} 102$ ASSEMBLY

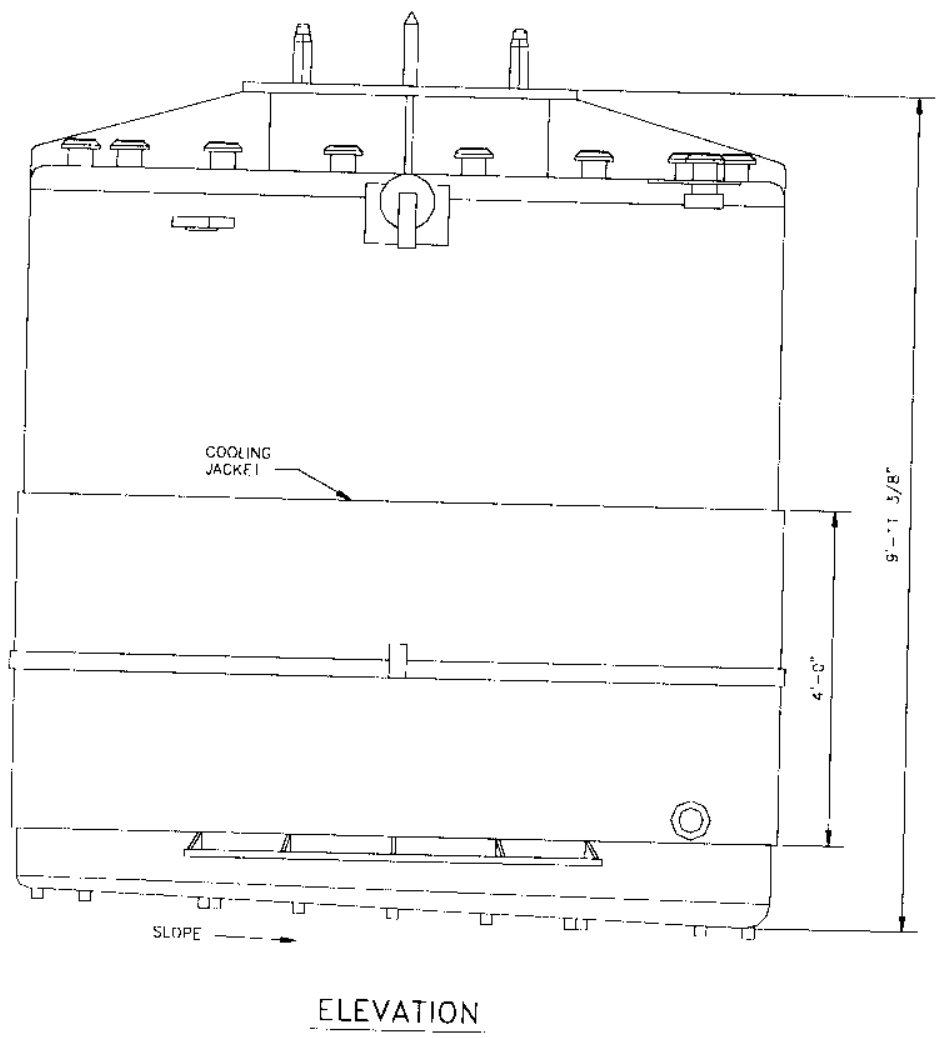




\subsection{Current System Description}

Radioactive liquid waste generated in the 222-S Laboratory enters into the collection system in the laboratory (i.e. hot cells, hoods, sumps, etc). The collection system is connected to a transfer system, which moves the waste to the 219-S Facility. There are four main transfer lines connected to the 219-S Facility. Two lines originate in the 11A hot cells and were installed by project $\mathrm{W}-041 \mathrm{H}$. The other two lines were installed by project W-087; one line originates in the T8 tunnel and one line originates in the T4 tunnel. The collection and transfer lines are encased (pipe in pipe) piping equipped with leak detection. Waste from the 11A hot cells is collected in Tank 101 and waste from T8 and T4 is collected in Tank 104. Tank 104 was added by Project W-178, 219-S Secondary Containment Upgrade. Once enough waste has accumulated in the collection tanks, the waste is transferred to Tank 102 for treatment. In Tank 102, the $\mathrm{pH}$ and nitrite levels of the waste are adjusted to meet tank farms waste acceptance criteria. The waste is transferred to tank farms by an air-operated pump and an underground transfer line (project W-087). The tanks are operated at a slight negative and vented through a HEPA filter. A sketch of the system is shown in Figure 2. The waste characteristics and tank operating parameters are shown in Table 1.

\subsection{INTEGRITY OF TANKS 101 AND 102 AND EXISTING COMPONENTS OF THE 219-S FACILITY}

The assessment of Tanks 101 and 102 will address the analytical design of the tanks, the current condition of the tanks, compatibility of the tank material with the waste to be stored or treated, and provide recommendations for future assessments. In addition, the assessment will address the components of 219-S Facility that will continue to be used in the tank system.

\subsection{Analytical Analysis}

Tanks 101 and 102 were fabricated from the same drawing (see Reference 2). Therefore, one analysis is adequate for both. An analysis was performed in 1990 as part the assessment for the 219-S Facility (see Reference 4, WHC-SD-CP-ER-030). The analysis was perform using the following codes and standards: SDC 4.1 (Reference 5), UCRL 15910 (Reference 6), UBC 1988 (Reference 7), ANSI/API 650 (Reference 8 ), and ASME Section VIII (Reference 9). These standards are still applicable. In the analysis, the tanks were evaluated for shell stresses, overturning stability, anchorage requirements, and nozzle reinforcement.

The results of the shell stress analysis demonstrates that the required wall thickness at the bottom of the tank is 0.062 inches and at the top of the tank 0.188 inches. The tanks were fabricated with shell thickness of the 0.5 inches. This shows that the tanks are over designed for the intended use. The additional thickness in the tank shell would allow for reduction due to corrosion.

The analysis showed the need for additional seismic restraints. These restraints were installed as part of project $W-178$. Seismic restraints were placed at the top and bottom of the tanks as shown in Figure 3. The analysis of the restraints is presented in calculation $\mathrm{W}-178-\mathrm{C0} 2$ (Reference 10). The analysis also demonstrated that nozzle reinforcement is not required. 
Figure 2,

Waste Transfer System

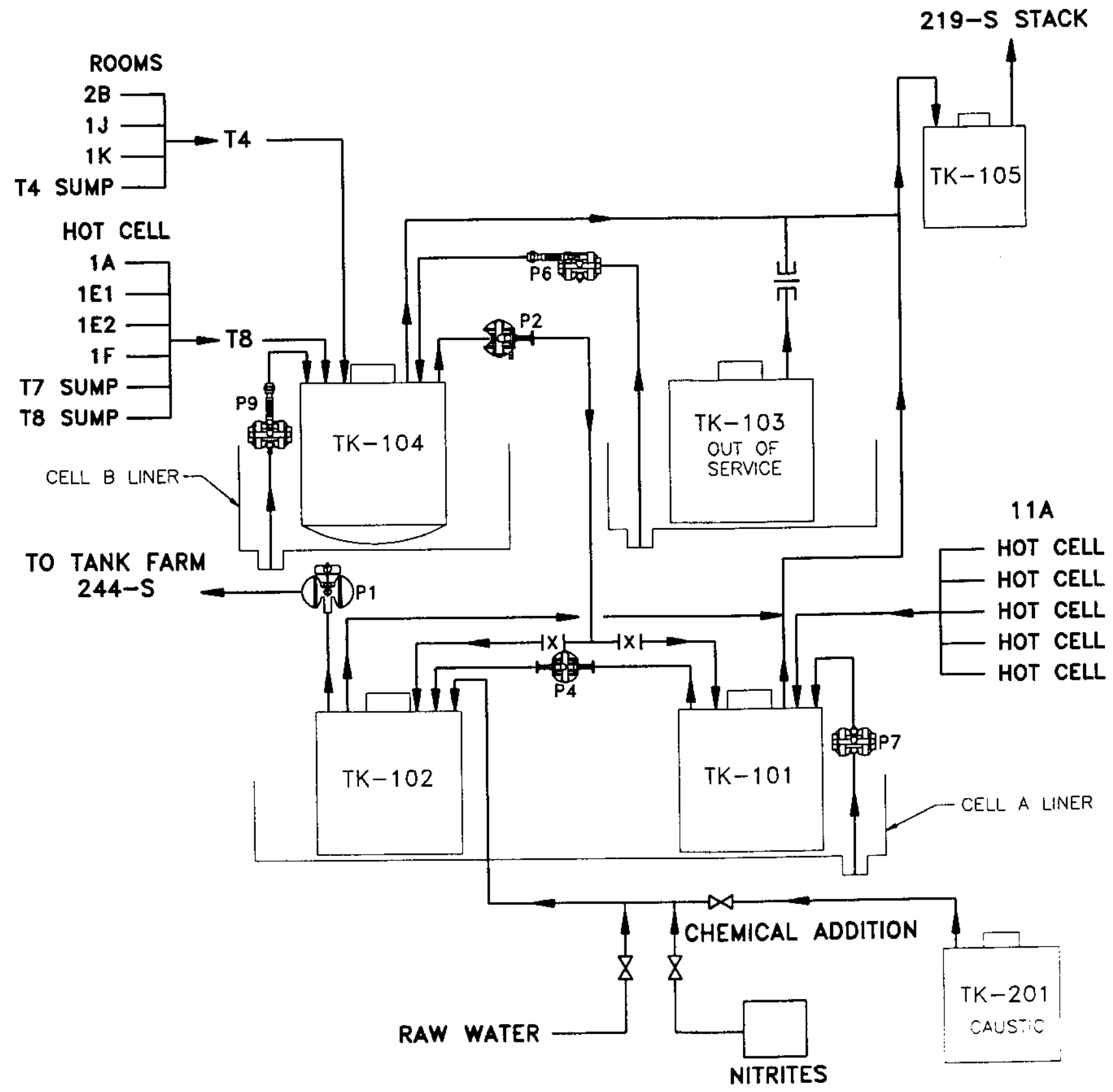


Table 1, Waste Characteristics and Tank Operation Parameters

\begin{tabular}{|l|l|l|}
\hline \multirow{4}{*}{ Fluid Properties } & Density & $1.0-1.1 \mathrm{~g} / \mathrm{cc}$ \\
\cline { 2 - 3 } & Viscosity & $0.3-3.0$ centipoise \\
\cline { 2 - 3 } & Solids Content & $0.0-5.0 \mathrm{vol} . \%$ \\
\cline { 2 - 3 } & $\mathrm{pH}$ & $0.5-14.0$ \\
\hline \multirow{5}{*}{ Radioactive Materials } & Total Alpha & $\leq 2.71 \mathrm{E}^{-3} \mathrm{Ci} / \mathrm{l}$ \\
\cline { 2 - 3 } & Total Beta & $\leq 1.18 \mathrm{Ci} / \mathrm{l}$ \\
\cline { 2 - 3 } & Strontium-89/90 & $\leq 2.88 \mathrm{E}^{-1} \mathrm{Ci} / \mathrm{I}$ \\
\cline { 2 - 3 } & Cesium-137 & $\leq 4.1 \mathrm{E}^{-1} \mathrm{Ci} / \mathrm{l}$ \\
\cline { 2 - 3 } & Uranium & $\leq 3.0 \mathrm{E}^{-1} \mathrm{Ci} / \mathrm{l}$ \\
\cline { 2 - 3 } & Plutonium & $\leq 2.0 \mathrm{E}^{-3} \mathrm{Ci} / \mathrm{l}$ \\
\hline \multirow{5}{*}{ Tank Operation Parameters } & Operating Temperature & $40^{\circ} \mathrm{F}-220^{\circ} \mathrm{F}$ \\
\cline { 2 - 3 } & Operating Pressure (psi) & 3.11 (Hydrostatic) \\
\cline { 2 - 3 } & $\begin{array}{l}\text { Specific Gravity of Fluid } \\
\text { - Design }\end{array}$ & $.95-1.4$ \\
\hline
\end{tabular}

See Reference 3

\subsubsection{Tank Condition}

The tank shell stresses analysis performed in 1990 shows that the tanks are over designed for the applied loads. Specifically, the analysis shows that the required thickness of the tank shell at the top of the tank should be 0.188 inches and at the bottom of the tank 0.062 inches. The thickness of the tanks when fabricated was 0.5 inches. To continue the use of the tanks, the tank shell condition must be evaluated. This was accomplished through two nondestructive inspection methods, a visual inspection and an ultrasonic test.

The tanks have been in service since 1951 and required cleaning prior to the inspection. Due to the lack of an agitator in Tank 101, solids accumulated in the tank both on the bottom and sides. The solids in the bottom of the tank were 4 to 6 inches deep and appeared to be fine sand or silt consistency mixed with laboratory debris (i.e. rubber stoppers, broken pipettes, etc). The solids on the bottom were loose and easily removed using a sluicing method with low-pressure water. The solids on the sides appeared to be a crust that adhered to the tank shell.

Tank 102 was equipped with an agitator to mix the waste after chemical addition. This agitation limited the accumulation of solids in the bottom of the tank. There was a build up of some substance, which had a strong bond on the sidewalls of the tank, probably due to years of $\mathrm{pH}$ and nitrite adjustments. 
Figure 3 ,

Seismic Restraints for Tanks 101 and 102

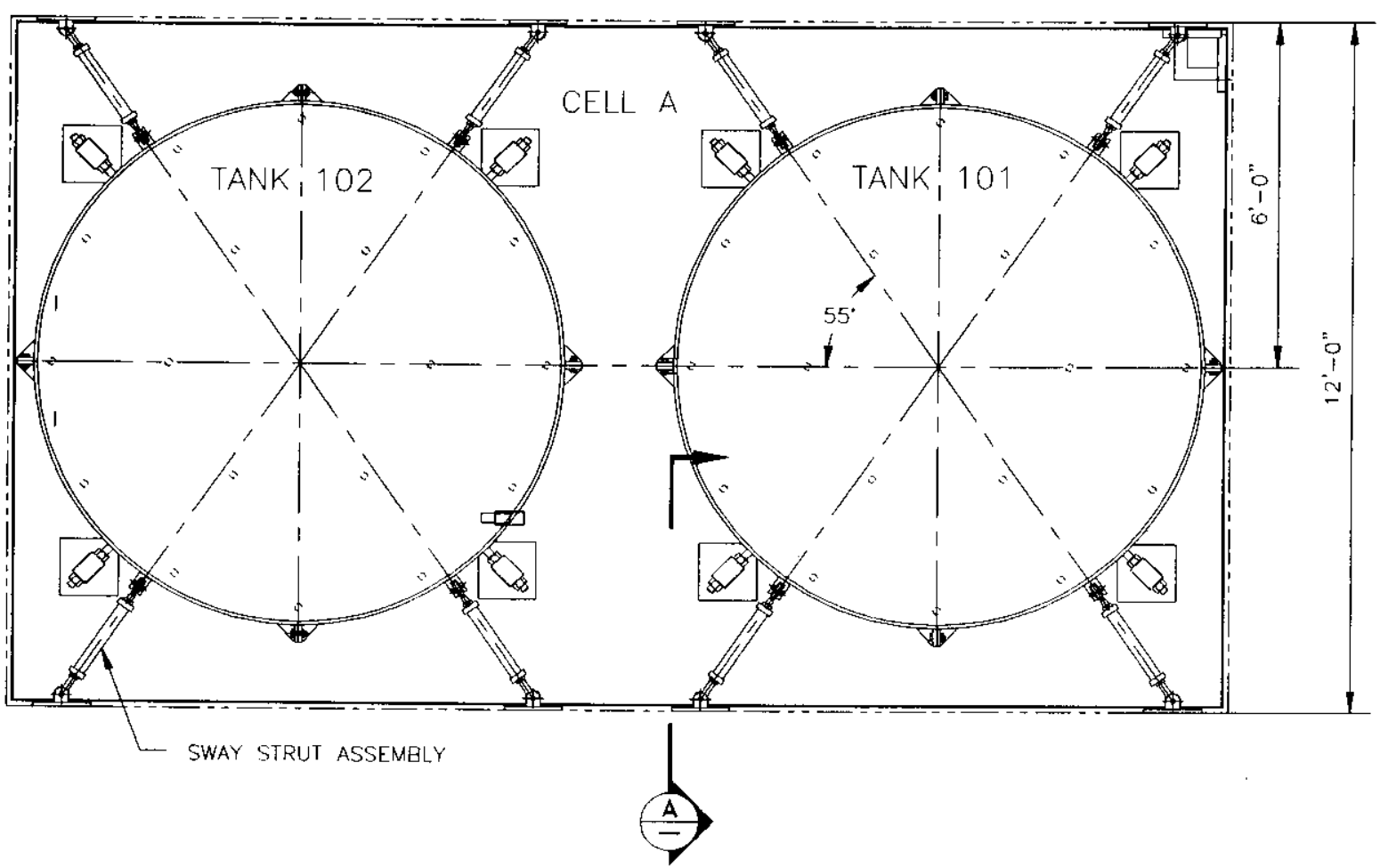

PLAN

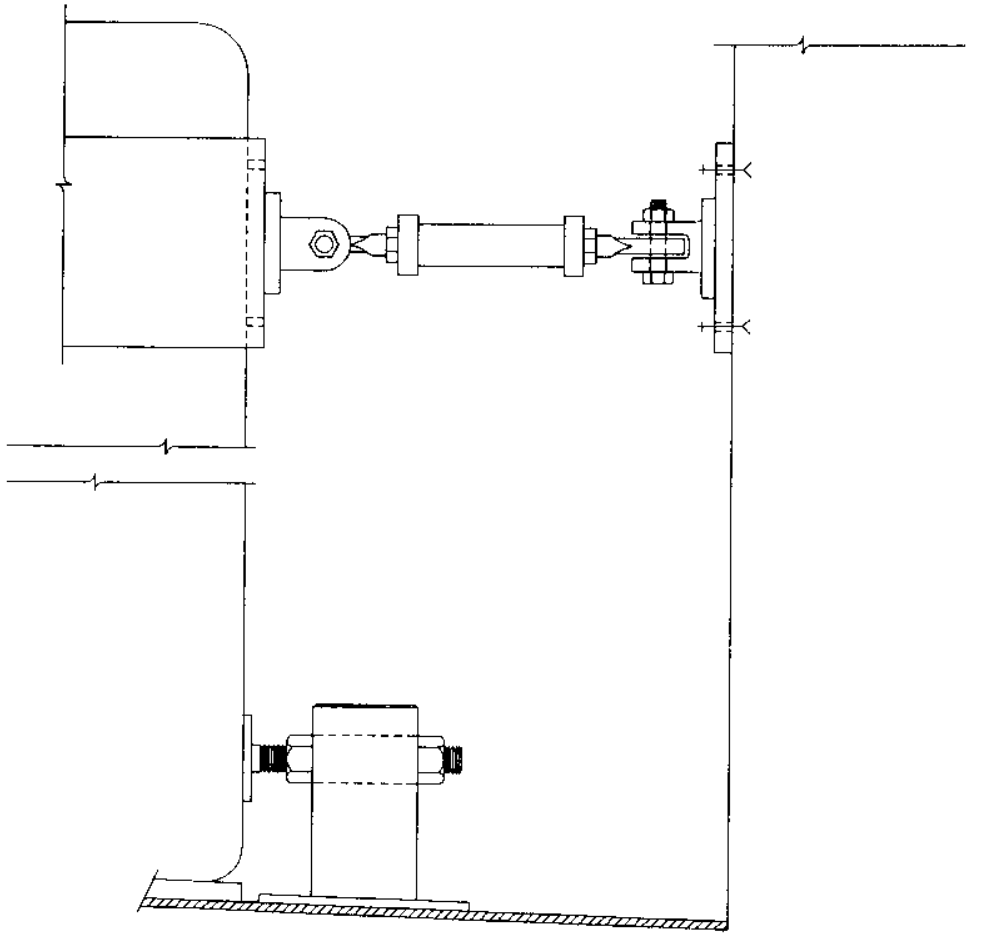

(4) $\frac{S E C T I O N}{\operatorname{schl}: 3=i^{\circ}-0^{\circ}}$ 


\subsubsection{Tank Cleaning}

Rev. 0

Three methods were used to remove the accumulated solids from the tanks. First, a high-pressure washer was used to remove solids from the sides. Second, low-pressure water was used to suspend the solids in solution while the solution was pumped out of the tank. Third, any solids remaining from method one and two were allowed to dry and were removed with a HEPA vacuum cleaner.

The approach to clean the tanks was to use the first two methods alternately to remove solids with a minimal amount of water. The high-pressure washer was a self-propelled device, which sprayed the water at $8000 \mathrm{psi}$. This was adequate to remove the crust from the sidewalls. A video of the inside of the tanks is available in the 222-S Laboratory regulatory file. Since the water used for cleaning created more waste, the tanks were only cleaned enough to facilitate the inspections.

\subsubsection{Visual Inspection}

The interior and exterior of the tanks were inspected, looking for areas that were discolored, cracked, or pitted. A Quality Control (QC) inspector performed a visual inspection of the tanks. $Q C$ inspector qualification information is located in Reference 11. Inspection of the tank interior was done using a video camera, since the radiological dose and contamination levels of the tank were too high for manned entry. The inspector saw what appeared to be some minor pitting in the video of the interior of the tank. However, when the same points are viewed with the camera at a different angle, the area of interest does not appear to be pitted. The inspector also found six areas with marks that are possibly cracks. There are five areas in Tank 101 and one area in Tank 102. When these points were viewed from a different camera angle, three of the marks in tank 101 could be dismissed. The pictures from the camera did not conclusively show the marks to be a crack. The marks might also be from a grinder during the original fabrication or a surface imperfection in the plate during the manufacturing process. Regardless of the origin of the marks they are not deep enough to cause the tank to fail or leak. See Reference 11 for the results of the visual inspection. The exterior of the tank was inspected, except for the area covered by the cooling jacket (see Figure 1). The results of the external examination show no defects on the tank shell.

\subsubsection{Ultrasonic Testing}

Ultrasonic testing (UT) was used to determine the thickness of the top, bottom, and sides of the tank shell. A qualified QC inspector following an approved procedure and using calibrated equipment performed UT testing (see Reference 11). Areas were selected at random for the UT. More than 150 measurements were taken on each tank with the minimum measurement being 0.48 inches (nominal 0.5 inches). The tank wall in the area under the cooling jacket was not measured since destructive removal of the cooling jacket would have been necessary to take the measurements. The decision not to remove the cooling jacket was made for the following reasons: first, the measurements taken demonstrate that the tank shell still has its original thickness; and second, the cooling jacket acts as an additional containment if the tank shell was to ever leak.

\subsection{Waste Compatibility}

The tanks are constructed from Type 347 stainless steel. The results of the nondestructive testing have shown that this material is resistant to the waste stream and after 47 years of service, there is negligible reduction in the tank shell from corrosion. This is significant given that in the past, there was little control of the quantity and concentration for chemicals poured into the drain system. Today, the 222-S Laboratory has procedures that control the pouring of chemicals into the drain system, which would be detrimental to the stainless steel. 


\subsection{Ancillary Equipment}

Only one section of pipe was reused in the system. This is the penetration between cell $A$ and $B$, labeled nozzle 81 . The spool piece was used in the system that transfers waste from Tank 104 and Tank 102. This nozzle was inspected prior to use and found to be acceptable. All other ancillary equipment is assessed in document HNF-4590 (see Reference 12).

\subsection{Concrete Vault and Secondary Containment}

Secondary containment is assessed in document HNF-4590 (see Reference 12). The concrete vauit was not used as secondary containment due to the unknown information regarding the installation. The vault is in good condition without signs of deterioration due to age (i.e., spalling, cracking etc). The original coating is deteriorating, however the new stainless steel liners protect the concrete. The vault structure was analyzed in 1990 as part of the 219 S Facility assessment and is structurally adequate (see Reference 4).

\subsection{Tank System Corrosion Assessment}

Not applicable as none of the existing tanks or ancillary equipment comes in contact with the soil.

\subsection{Disposition of Unfit-for-Use Tank Systems}

Not applicable.

\subsection{Extensive Repairs}

No extensive repairs were made to either tank. A minor modification to the support posts were required. The original design and fabrication of the tank used nineteen, 2 -inch diameter, stainless steel posts for support. These stainless steel posts were 1-4 inches long, with 6-inch diameter carbon steel plates welded to the end. The posts were evenly distributed on the bottom of the tank. The carbon steel plates required removal, due to the corrosion of the carbon steel and the incompatibility of carbon steel with the stainless steel liner installed by project $W 178$. The tanks were modified by cutting the 2 -inch diameter supports off, above the carbon steel plates. This was done while the tanks were removed for installation of the secondary containment liner. The removal work was inspected by $Q C$ to ensure that the tank was not damaged. With the supports removed, the tanks are supported around the edge. This method of support was analyzed and found acceptable (see calculation W-178-C07, Reference 13). 


\subsection{CONCLUSION}

\subsection{Tank Condition}

Tanks 101 and 102 are structurally sound with some possible small cracks and minor pitting. The UT correlates with the visual inspection that the tank shell and the welds are still a nominal 0.5 inches thick. The results demonstrate that, after 47 years of service, the waste placed in the tanks has not significantly degraded the tanks. Therefore, as long as the waste criteria or the operational parameters do not significantly change, it can be expected that the tanks will remain functional for the next 30 years without concern of a major structural failure. Any minor leaks that might occur in the next 30 years would be contained and detected in the new secondary containment and repair could be made.

\subsection{Future Assessments}

This assessment demonstrates that, after 47 years of service, the tanks are in excellent condition. The analysis performed in 1990 shows that a minimum tank shell thickness of 0.188 inches is all that is necessary to contain a full tank of waste. The information from these assessments demonstrates that there is no need for additional assessments of this magnitude for the tanks to operate for the next 30 years. Therefore, the recommendation from this assessment is that no further assessments or testing are required for the tanks to operate safely for the next 30 years.

\subsection{STRUCTURAL INTEGRITY ASSESSMENT STATEMENT}

I certify under penalty of law that this document and all attachments were prepared under my direction or supervision in accordance with a system designed to assure that the qualified personnel properly gathered and evaluated the information submitted. Based on my inquiry of the person or persons who manage the system, or those persons directly responsible for gathering the information, the information submitted is, to the best of my knowledge and belief, true, accurate, and complete. I am aware that there are significant penalties for submitting false information, including the possibility of a fine and imprisonment for knowing violations.

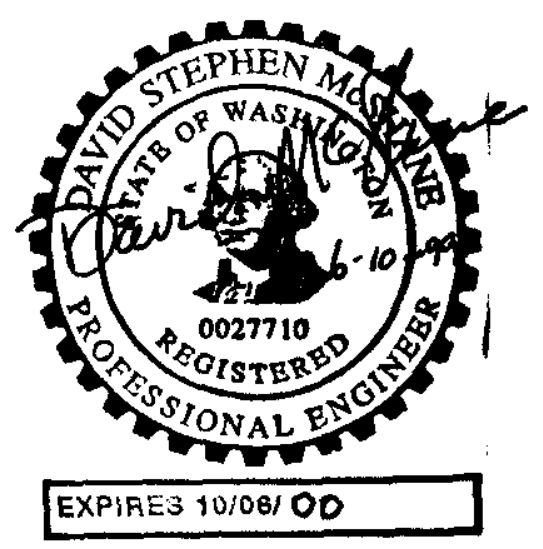




\subsection{REFERENCES}

1. WAC 173-303, Section 640, "Tank Systems", January 1998

"Dangerous Waste Regulations"

2. Drawing H-2-5233, Sheet 1, Rev 2

"Piping, WT-TK-101 \& WT-TK-102 Modifications"

3. HNF-SD-W178-FDC-001, Rev 3, June 19, 1998

"Functional Design Criteria, 219-S Secondary Containment Upgrade"

4. WHC-SD-CP-ER-030, Rev 0, July 6, 1990

"219-S Aqueous Waste Disposal Facility Tank System Integrity Assessment Report"

5. Hanford Plant Standard, SDC 4.1, Rev. 11, 1989

"Architectural-Civil Design Criteria Design Loads for Facilities"

6. UCRL 15910, 1988

"Design and Evaluation Guidelines for Department of Energy (DOE) Facilities Subjected to Natural Phenomena Hazards"

7. UBC 1988, Uniform Building Code

"International Conference of Building Officials," Whittier, CA

8. ANSI/API 650, Rev. 1, 1984 Welded Steel Tanks for Oil Storage

"American Petroleum Institute," Washington, D.C.

9. ASME Section VIII, 1989, ASME Boiler Pressure Vessel Code "American Society of Mechanical Engineers," New York, NY

10. Calculation W-178-C02, W-178, "219-S Secondary Containment Upgrade Calculation Item: "Seismic Restraints for Tank 101 and Tank 102 and Cell A Liner"

11. HNF-4621, Rev 0, June 1999

"Data Report for the Integrity Assessment Report HNF-4589"

12. HNF-4590, Rev 0, June 1999

"Integrity Assessment Report for Project W-178"

13. Calculation W-178-C07, W-178, "219-S Secondary Containment Upgrade

Calculation Item: "Analysis of Tank With Curved Bottom" 